\title{
The caudate lobe described by Adriaan van den Spiegel
}

\author{
Thomas M. van Gulik
}

Department of Surgery, Amsterdam University Medical Centers, University of Amsterdam, Amsterdam, The Netherlands

Correspondence to: Thomas M. van Gulik, MD. Department of Surgery, Amsterdam University Medical Centers, University of Amsterdam, Amsterdam, The Netherlands. Email: t.m.vangulik@amsterdamumc.nl.

Submitted Nov 02, 2021. Accepted for publication Nov 13, 2021.

doi: $10.21037 / \mathrm{hbsn}-2021-24$

View this article at: https://dx.doi.org/10.21037/hbsn-2021-24

Adriaan van den Spiegel [1578-1625] was born in the Flemish city of Brussels. He studied medicine in Louvain (Belgium) and Leiden (The Netherlands) and early on showed a keen interest in anatomical dissections (1). Also known as 'Spigelius' in Latin, he was appointed professor of dissection and surgery at the famous medical faculty of the University of Padua in Italy.

In Padua, van den Spiegel published an anatomical atlas in 1627 , containing anatomical plates, many of which were derived from an atlas compiled by his predecessor, the anatomist Giulio Casseri [1552-1616] (2). Van den Spiegel was the first to describe in his atlas, a small lobe situated at the backside of the liver, that from then on was referred to as Spiegel's lobe (lobus Spigelli). The particular illustration of the liver in his atlas shows the liver in a reversed position, with the fundus of the gallbladder (E) turned downwards and Spiegel's lobe $(\mathrm{M})$ in front of the caval vein $(\mathrm{C})$. Although the lobe was depicted on the same plate in the earlier book by Casseri, the lobe became eponymously attached to Van den Spiegel. Later on, Spiegel's lobe was termed the caudate lobe (lobus caudatus) by anatomists, and defined as 'segment 1 ' by the French surgeon-anatomist, Claude Couinaud.

Adriaan van den Spiegel died in 1625 from a septic condition. At autopsy, an intra-abdominal abscess was found, ironically adjacent to the caudate lobe, the lobe he had described and that bore his name, Spiegel's lobe.

\section{Acknowledgments}

Funding: None.

\section{Footnote}

Provenance and Peer Review: This article was commissioned by the editorial office, Hepatobiliary Surgery and Nutrition. The article did not undergo external peer review.

Conflicts of Interest: The author has completed the ICMJE uniform disclosure form (available at https://hbsn. amegroups.com/article/view/10.21037/hbsn-2021-24/coif).



TMvG serves as an unpaid editorial board member of Hepatobiliary Surgery and Nutrition. The author has no other conflicts of interest to declare.

Etbical Statement: The author is accountable for all aspects of the work in ensuring that questions related to the accuracy or integrity of any part of the work are appropriately investigated and resolved.

Open Access Statement: This is an Open Access article distributed in accordance with the Creative Commons Attribution-NonCommercial-NoDerivs 4.0 International License (CC BY-NC-ND 4.0), which permits the noncommercial replication and distribution of the article with the strict proviso that no changes or edits are made and the original work is properly cited (including links to both the formal publication through the relevant DOI and the license). See: https://creativecommons.org/licenses/by-nc-nd/4.0/.

\section{References}

1. van de Spiegel A. De Humani Corporis Fabrica Libri Decem. Frankfurt 1632, Wellcome Collection, L0032415.

2. Ghosh SK, Sharma S, Biswas S, et al. Adriaan van den Spiegel (1578-1625): anatomist, physician, and botanist. Clin Anat 2014;27:952-7.

Cite this article as: van Gulik TM. The caudate lobe described by Adriaan van den Spiegel. HepatoBiliary Surg Nutr 2021;10(6):748. doi: 10.21037/hbsn-2021-24 